\title{
A Review of the Mullets with a Keel on the Back, Liza carinata Complex (Pisces : Mugilidae)
}

\section{$\operatorname{AUTHOR}(\mathrm{S})$ :}

Senou, Hiroshi; Yoshino, Tetsuo; Okiyama, Muneo

\section{CITATION:}

Senou, Hiroshi ...[et al]. A Review of the Mullets with a Keel on the Back, Liza carinata Complex (Pisces: Mugilidae). PUBLICATIONS OF THE SETO MARINE BIOLOGICAL LABORATORY 1987, 32(4-6): 303-321

\section{ISSUE DATE:}

1987-12-26

URL:

http://hdl.handle.net/2433/176141

RIGHT: 


\title{
A Review of the Mullets with a Keel on the Back, Liza carinata Complex (Pisces: Mugilidae)
}

\author{
By \\ Hiroshi Senou \\ Ocean Research Institute, University of Tokyo, 1-15-1, \\ Minamidai, Nakano-ku, Tokyo, 164, Japan \\ Tetsuo Yoshino \\ Department of Marine Sciences, University of the Ryukyus, 1, Senbaru, \\ Nishihara-cho, Nakagami-gun, Okinawa Pref., 903-01, Japan \\ and \\ Muneo Okiyama \\ Ocean Research Institute, University of Tokyo, 1-15-1, \\ Minamidai, Nakano-ku, Tokyo, 164, Japan
}

With Text-figures $1-5$ and Tables $1-2$

\begin{abstract}
Liza carinata complex, characterized by having a keel on the middorsal line in front of the spinous dorsal fin, is revised. This complex consists of the following three species: L. carinata ([Ehrenberg MS] Valenciennes in Cuvier \& Valenciennes, 1836) occurs in the Red Sea and the eastern Mediterranean; L. klunzingeri (Day, 1888) occurs in the west coast of India, Pakistan and the Arabian Gulf (Persian Gulf); L. affinis (Günther, 1861) occurs in China, Taiwan and Japan. A key, synonymies, descriptions and illustrations are provided for all these species. Some geographical variations are also discussed.
\end{abstract}

Liza carinata complex is a distinct group characterized by having a keel on the middorsal line in front of the spinous dorsal fin. The members of this complex are distributed discontinuously in the tropical and temperate Indo-West Pacific region of the Northern Hemisphere, inhabiting estuarine and shallow coastal waters. They are unwarranted for being monophyletic and have been much confused taxonomically each other. However, it is evident that they belong to a distinct genus Liza Jordan \& Swain, 1884 which is characterized by having a pair of elongated posterior neural zygapophysis on the second vertebra.

Mugil carinatus ( $=L$. carinata) was described by Valenciennes in Cuvier \& Valenciennes (1836) on the basis of some materials from the Red Sea that Ehrenberg might have sent to him (Trewavas \& Ingham, 1972). Although his description of this species is not fully diagnostic, he described clearly on the keel on the back.

Publ. Seto Mar. Biol. Lab., 32 (4/6), 303-321, $1987 . \quad$ (Article 10) 
In one of his great works, Day (1876) reported $M$. carinatus with full description on the basis of plural specimens from the Indian waters. After that, Day (1888a) named $M$. klunzingeri (=L. klunzingeri) to the description and figure of Day (1876) according to Klunzinger's advice, and he newly added $M$. carinatus with full description from the Indian waters. Day (1889) provided a key to the mugilid fishes including these both species with the Red Sea as one of the localities. Pillay (1962) regarded $M$. carinatus and $M$. klunzingeri as the same species in a review of the Indian Mugilidae. Recently, however, Trewavas \& Ingham (1972) stated that L. klunzingeri from the Indian waters differs from $L$. carinata from the Red Sea only in having usually a lower number of scales, and L. klunzingeri is a subspecies of L. carinata.

On the other hand, Japanese and Chinese ichthyologists have traditionally used the name, $M$. carinatus or $L$. carinata for a mugilid fish which has a keel on the back, and is commonly found in these regions since Oshima $(1919,1922)$ erroneously identified L. affinis ( $=M$. affinis Günther, 1861) as $M$. carinatus. $M$. affinis was described by Günther (1861) on the basis of a specimen from Amoy, China. Although his description is detailed, he did not describe on the keel on the back. Recently, Song (1981) who is a reviewer of the Chinese mugilids used the name, affiris for Osteomugil ophuyseni (Bleeker, 1859) (=M. cunnesius Valenciennes in Guvier \& Valenciennes, 1836).

In the present paper, we have reviewed $L$. carinata complex on the basis of the specimens from nearly all previously known localities including the type materials, and recognized the following three species: L. carinata ([Ehrenberg MS] Valenciennes in Cuvier \& Valenciennes, 1836) occurs in the Red Sea and the eastern Mediterranean; L. klunzingeri (Day, 1888) occurs in the west coast of India, Pakistan and the Arabian Gulf (Persian Gulf); L. affinis (Günther, 1861) occurs in China, Taiwan and Japan.

\section{Materials and Methods}

Specimens examined are deposited in the Australian Museum, Sydney (AMS); Academy of Natural Sciences, Philadelphia (ANSP); British Museum (Natural History), London (BMNH); Museum National d'Histoire Naturelle, Paris (MNHN); Museum of the Tokyo University of Fisheries, Tokyo (MTUF); the Department of Marine Sciences, University of the Ryukyus, Okinawa (URM); National Museum of Natural History, Washington, D.C. (USNM); the Western Australian Museum, Perth (WAM); Yokosuka City Museum, Yokosuka (YCM); Zoological Survey of India, Calcutta (ZSI); and Department of Zoology, University Museum, University of Tokyo, Tokyo (ZUMT).

Counting methods of meristic characters mainly follow Hubbs \& Lagler (1947). In the present study, counts of pectoral, second dorsal and anal fins are not divided into branched and unbranched soft rays. The number of pectoral fin rays is included the uppermost rudimentary ray. Lateral scale series represents the number of scales on the midlateral scale row from the upper end of opercle to the caudal base. Transverse scale rows represent the number of scale rows between the spinous dorsal and anal origins, and a scale row on middorsal line is excluded. In cheek scale rows, although the scales on lower part of preopercle are arranged irregularly, these scales are regarded as one row. The number of vertebrae is counted from soft $\mathrm{X}$-ray negatives. The first caudal vertebra is the first vertebra bearing a modified hemal spine. The distal end of the hemal spine bends backward in parallel or nearly so with the centrum, thus giving L-form in lateral view. Hypurals and urostyle are regarded as the ultimate vertebra. 
In the present study, all measurements except angle of lower jaw were taken with fine pointed dividers or vernier calipers to the nearest $0.1 \mathrm{~mm}$, and are expressed in hundredths of standard length. The measuring methods of total length, standard length, caudal peduncle length and interorbital width follow Hubbs \& Lagler (1947). The following measurements follow Grant \& Spain (1975): Fork length; prefirst dorsal fin length; presecond dorsal fin length; prepelvic fin length; preanal fin length; preanus length; eye diameter; adipose eyelid length; adipose eyelid gap; thickness at pectoral fins; thickness at first dorsal fin; depth at eye; depth at pectoral fin; depth at first dorsal fin; caudal peduncle depth; pectoral fin length; pectoral fin base length; axillary scale length; first dorsal fin base length; dorsal obbasal scale length; second dorsal fin height; second dorsal fin base length; pelvic fin length; anal fin height; and anal fin base length. Postfirst dorsal fin length is the distance between the anterior base of erect first dorsal fin and the middle of caudal fin base. Prepectoral fin length is the distance between the tip of snout and the anteriormost point of the base of the depressed pectoral fin. The distance between first and second dorsal fins is the distance between the anterior bases of each fin when the fins erected. Head length is the maximum distance between the tip of snout and the middle part of the posterior margin of opercle except gill membrane. Postorbital length is the maximum distance between the posterior extreme of eye and the middle part of the posterior margin of opercle except gill membrane. Preadipose eyelid length is the distance between the anterior extremes of the eyelid and the adipose eyelid gap. Postadipose eyelid length is the distance between the posterior extremes of the eyelid and the adipose eyelid gap. The thickness at second dorsal fin is the width of body, perpendicularly through the anterior insertion of second dorsal fin. The distance between anterior and posterior nostrils is the distance between the midpoints of posterior margin of each nostril. The width of mouth is the distance between the mouth corners when mouth closed. The thickness of upper lip is the width of upper lip at the middle. The lower jaw length is the distance between the anterior extreme of lower jaw and the left mouth corner. The angle of lower jaw $(A L J)$ is the angle formed by the right and left anterior edges of lower jaw in ventral view. This angle was calculated by the lower jaw length (LJL) and the width of mouth (WM). The expression is as follows: ALJ $\left({ }^{\circ}\right)=180-2 \cos ^{-1}(\mathrm{WM} / 2 \mathrm{LJL})$. The depth at mouth corner is the distance between the dorsal and ventral surface of the head, perpendicularly through the mouth corner. The depth at anal fin is the depth of body, perpendicularly through the anal fin origin. The first dorsal spine length is the distance between the base of anterior face and the tip of erect first dorsal spine. The second dorsal spine length is the distance between the midbase of lateral face and the tip of erect second dorsal spine. The third dorsal spine length is the distance between the midbase of lateral face and the tip of erect third dorsal spine. The fourth dorsal spine length is the distance between the base of posterior face and the tip of erect fourth dorsal spine. The interpelvic flange length is the distance between the anterior insertion of erect pelvic fin and the posterior tip of interpelvic flange.

In the present paper, observation of teeth on the lips was done under stereoscopic microscope and scanning electron microscope. Terminology on the teeth morphology follows Ebeling (1957).

\section{Taxonomy}

Key to the species of the keeled back Liza

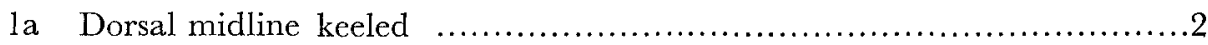

Ib Dorsal midline not keeled.............................other Liza species

$2 \mathrm{a}$ Pectoral fin length $14.5-18.4 \%$ of SL; head length $22.1-26.9 \%$ of SL... L. affinis (Günther)

2b Pectoral fin length $19.8-23.9 \%$ of SL; head length $27.0-31.3 \%$ of SL......3

$3 a$ Total gill rakers 79-96 (66.3-91.0 mm SL), 94-109 (110.1-138.6 mm SL); 3rd predorsal and 1st pterygiophore of 1st dorsal fin set between 6 th and 7 th, 7 th and 8 th vertebrae respectively........... klunzingeri (Day)

3b Total gill rakers 69-82 (66.9-95.5 mm SL), 83-93 (106.0-124.1 mm 
SL); 3rd predorsal and 1st pterygiophore of 1st dorsal fin set between 5 th and 6 th, 6 th and 7 th vertebrae respectively

L. carinata ([Eh.] Valenciennes)

\section{Liza carinata ([Ehrenberg] Valenciennes)}

(Fig. 1 and Fig. 5)

Mugil carinatus (part) [Ehrenberg MS] Valenciennes in Cuvier \& Valenciennes, 1836: 148 (Ten syntypes from the Red Sea, Guam Is., Bombay, Pondichery and Seychelles); Day, 1865: 145 (reference).

Liza carinata: Ben-Tuvia, 1966: 263 (Port Said, the Suez Canal, Gulf of Suez); Ben-Tuvia, 1975: 17 (key), fig. 1c (Gulf of Suez); Dor, 1984: 191 (listed).

Liza carinata carinata: Trewavas \& Ingham, 1972: 17 (key), 24-26 (the coast of Nile Delta, Bardawil, the Suez Canal, Gulf of Suez).

Liza (Liza) carinata carinata: Trewavas, 1973: 572 (listed).

Materials examined: MNHN A. 3643 (Lectotype), 1 specimen, $86.9 \mathrm{~mm}$ in SL, the Red Sea, coll. by Ehrenberg. MNHN 1987-1322 (formerly A. 3643) (Paralectotype), 1 specimen, 80.0, same data as Lectotype. MNHN 1966-442, 11 specimens, 42.2-96.2, Gulf of Suez, coll. by Dollfus. MNHN 1966-443, 15 specimens, 66.9-124.1, Hammam Faraoun, Gulf of Suez, coll. by Dollfus. ZUMT 56752, 1 specimen, 87.7, Et Tur, Gulf of Suez, Jan. 20, 1972.

Description: Counts and proportional measurements are shown in Tables 1 and 2, and Fig. 2.

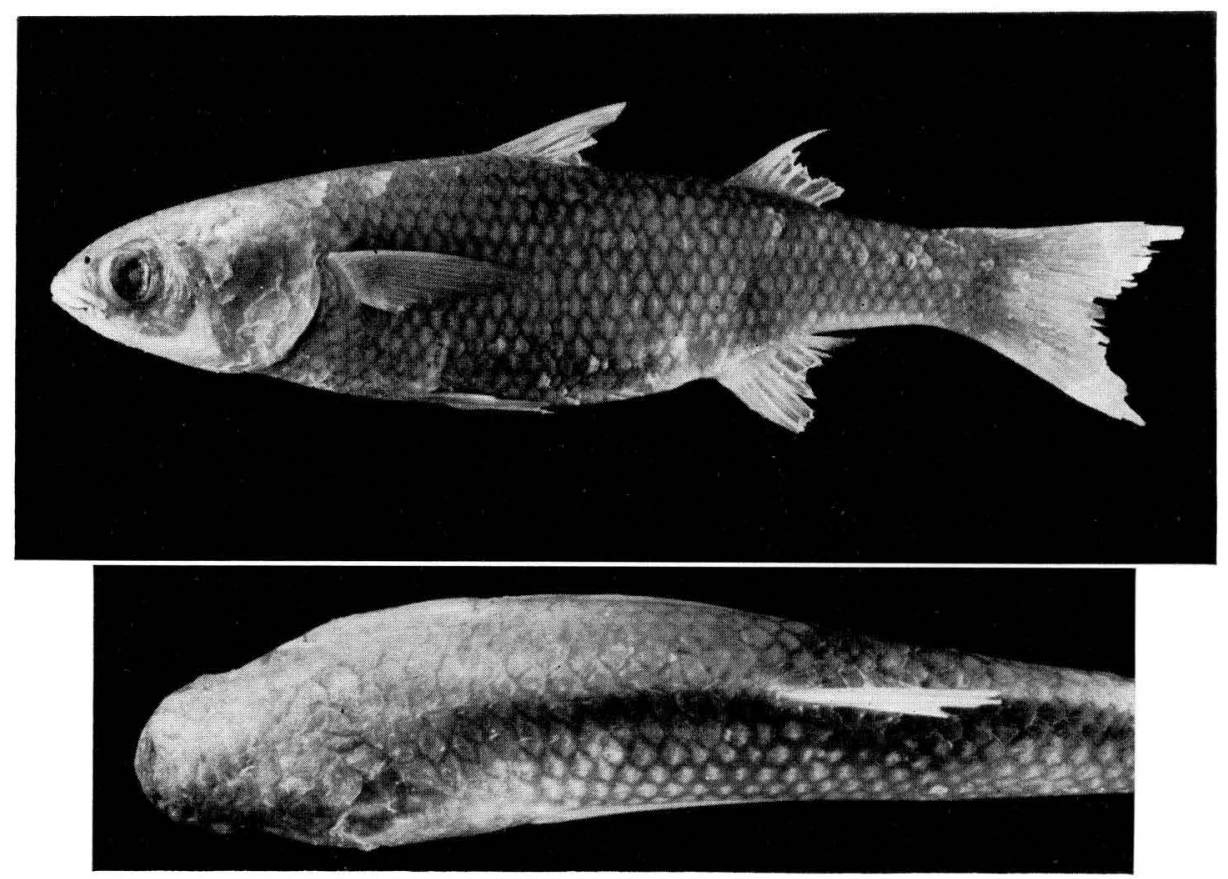

Fig. 1. Liza carinata ([Ehrenberg MS] Valenciennes). Upper, $118.9 \mathrm{~mm} \mathrm{SL,} \mathrm{MNHN}$ 1966-443; lower, dorsal view of the same specimen. 
Body moderately short and compressed. Middorsal line keeled in front of 1st dorsal fin, the keel frequently weak. No keel between 1st and 2nd dorsal fins.

Head large, interorbital space convex in front view. Adipose eyelid widely developed anteriorly and posteriorly, but the posterior adipose eyelid thin. Posterior margin of adipose eyelid gap reaching between the posterior margin of pupil and the middle point between the posterior margins of pupil and eye.

Maxillary curved downwards at mouth corner, the tip reaching beyond mouth corner. The tip exposed when mouth closed. Connecting tissue between the end of maxillary and mouth corner well developed, visible when mouth closed (Fig. 5B).

Lachrimal serrated in the lower and posterior edges. Serration of the lower edge limited in the posterior part of mouth corner. The lower edge of lachrimal slightly emarginate or nearly straight at mouth corner. Posterior edge narrow, the upper end not reaching the margin of eye.

Mouth terminal, with a prominent symphysial knob at tip of lower jaw. Upper lip not thick, bearing a row of primary teeth in the lower edge. Teeth minute and ciliform, invisible by naked eye. Space between teeth narrow, nearly same as the width of tooth. Individual tooth elongate, cylindrical, and slightly curved inward. The tip somewhat depressed with small neck. Edge of the tip round. A row of very minute secondary teeth rarely observed. Lower lip forming thin edge, directed horizontally forward. Teeth on lower lip not observed. Mouth corner on a vertical line through posterior nostril.

Tongue with a longitudinal lower ridge of right or obtuse angle in front view. The ridge frequently indistinct in larger specimens. The tip more or less free, rarely adhering to mouth floor.

Ventral inner edges of right and left dentaries connected each other with a very short joint at symphysis. The free space formed by both edges of the dentaries very wide at the just behind of symphysis, the width gradually narrowing toward the posterior part of mandible.

Gill opening extending below between the middle point between center and posterior margin of pupil and the posterior margin of eye. Gill rakers moderately long with two rows of minute fringes, the tips pointed. The longest raker on lower arch, its length 2.0-2.2 in the longest gill filament.

Scales on body weakly ctenoid, relatively strong in the ventral part. Interorbital space covered with weak ctenoid scales, the median scales reaching beyond anterior nostrils, the anterior scales minute. Lachrimal and mandible with minute scales. Second and third dorsal spines with a row of minute scales on their basal halves of outer edges. Second dorsal fin naked except the anterior and basal parts of the fin. Outer surface of pectoral, inner surface of pelvic, anal and caudal fins also covered with minute scales. Most of scales on body with a simple and elongate sensory canal.

Stomach with well developed biconical gizzard. Each pyloric caecum with a simple tip.

Three predorsals, set between 2nd and 3rd, 4th and 5th, 5th and 6th vertebrac 
respectively. First pterygiophore of spinous dorsal fin set between 6 th and 7 th vertebrae. Posterior neural zygapophysis on 2nd vertebra very long and slender, projecting postero-dorsally like antenna.

Color in preserved specimen: Dorsal dark, pale in the lateral and ventral side of body, without any distinct marking.

Distribution: Known only from Gulf of Suez, the Suez Canal zone, the coast of Nile Delta and the Bardawil Lagoon (the north coast of Sinai Peninsular, the eastern Mediterranean). The original distributional range before the construction of Suez Canal is unknown (Trewavas \& Ingham, 1972).

Remarks. Valenciennes' type materials of this nominal species consist of ten syntypes (Blanc \& Hureau, 1972): MNHN A. 3643, 2 specimens from the Red Sea, coll. by Ehrenberg; MNHN A. 3629, 1 specimen from Guam Island, coll. by Quoy and Gaimard; MNHN A. 3619, 1 specimen from Bombay, coll. by Dussumier; MNHN A. 3631, 2 specimens from Pondichery, coll. by Raynauld; MNHN A. 3820, 4. specimens from Seychelles, coll. by Dussumier. Of these specimens, A. 3643 only is a species known as L. carinata with a keel on the back. Although the other specimens are young fish, and their complete identification is difficult, we identified them as the following: A. 3629: Valamugil sp.; A. 3619: L. sp.; A. 3631: L. sp.; A. 3820: $V$. seheli. In addition to this result, Valenciennes' description and the heading of "Mugil carinatus, Ehrenb." suggest that his description was done on the basis of A. 3643. We therefore designate a larger specimen of A. 3643 as lectotype, another one as paralectotype.

As some authors such as Pillay (1962) and Thomson (1984) regarded both $L$.

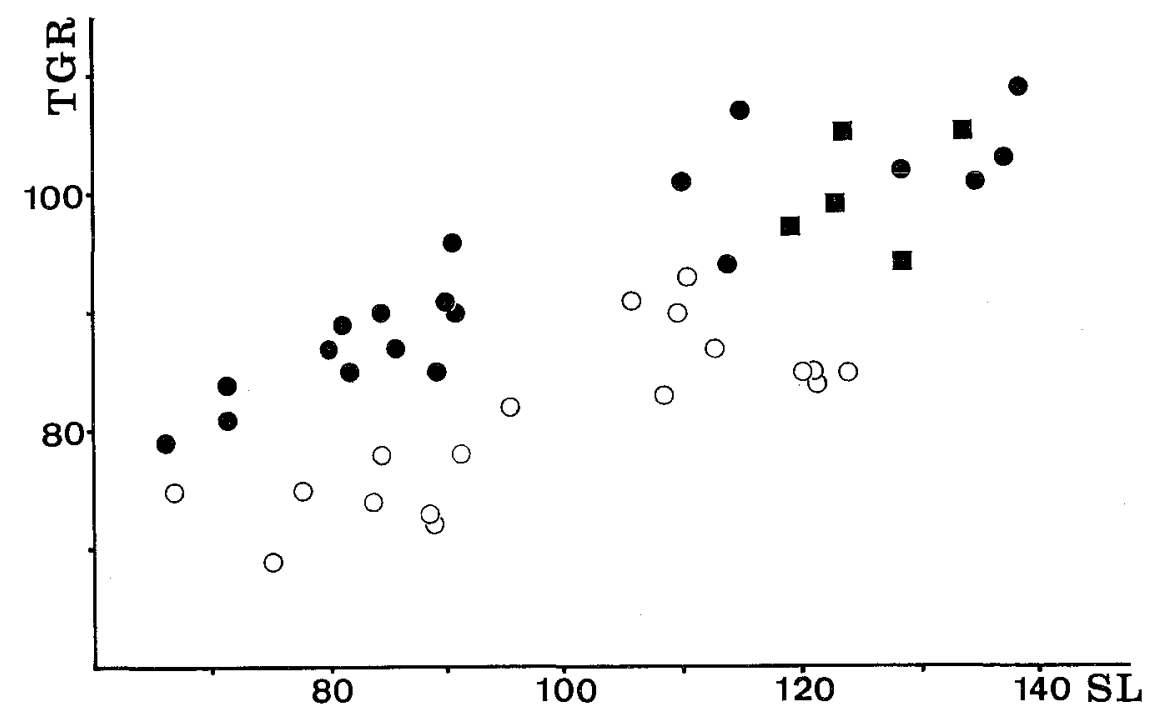

Fig. 2. Relation of number of totall gill rakers (TGR) to standard length (SL mm) for Liza carinata from the Red Sea (O), L. klunzingeri from the Arabian Gulf (O), L. klunzingeri from Pakistan ( $\mathbf{\square}$. 
carinata and L. klunzingeri as same species, these two species are very alike in its general physiognomy. Trewavas \& Ingham (1972) treated them as subspecific twin basing on the difference in the number of lateral scale series. In the present study, however, we found that $L$. carinata is distinguishable from $L$. klunzingeri in the number of total gill rakers (see Fig. 2) and the positions of 3rd predorsal and 1st pterygiophore of spinous dorsal fin (see key). We consider that they should be treated as different species.

\section{Liza klunzingeri (Day, 1888)}

(Fig. 3 and Fig. 5)

Mugil carinatus (not of Valenciennes): Day, 1876: 349, pl. 74, fig. 2 (Bombay and seas of India); Day, 1888b: 800 (seas of India); Day, 1889: 344 (seas of India); Pillay, 1962 (part ?): 548, pl. 1, fig. 1 (Bombay, Sind and Karachi).

Mugil klunzingeri Day, 1888a: 264 (designation of Mugil carinatus in Day, 1876); Day, 1888b: 800 (correction for Mugil carinatus in Day, 1876); Day, 1889: 343 (seas of India).

Liza macrolepis (not of Smith): Kuronuma \& Abe, 1986: 207, pl. 24 (top fig.) (Kuwait and Iraq, Arabian Gulf).

Materials examined: ZSI 1407 (Lectotype), 1 specimen, $102.1 \mathrm{~mm}$ in SL, Bombay, coll. by F. Day. ZUMT 56071-56080, 10 specimens, 119.5-133.8, Karachi, Pakistan, Mar., 1987. MTUF-P 20435, 24 specimens, 80.0-94.7, Sulaibikhat, Kuwait Bay, Mar. 25, 1969. MTUF-P 20437, 2 specimens, 114.0-115.2, Shuwaik, Kuwait Bay, Jul. 4, 1969. MTUF-P 20438, 7 specimens, 128.0-142.0, Kuwait City market, Jul. 10, 1966. MTUF-P 20439, 5 specimens, 112.9-135.8, Fahaheel fish market, Kuwait, Nov. 10, 1969. MTUF-P 20458, 6 specimens, 66.3-110.1, fish pond, Basrah University, Iraq, Jan. 23, 1969.

Description: Counts and proportional measurements are shown in Tables 1 and 2, and Fig. 2.

Body short, well compressed. Middorsal line keeled in front of 1 st dorsal fin. The keel well developed, forming sharp edge, but sometimes weak in the specimens from the Arabian Gulf. No keel between 1st and 2nd dorsal fins.

Head large, interorbital space slightly convex in front view. Adipose eyelid widely developed anteriorly and posteriorly, but relatively thin in the posterior part. Posterior margin of adipose eyelid gap reaching between the posterior marign of pupil and the middle point between the posterior margins of pupil and eye.

Maxillary curved downward at mouth corner, the tip reaching beyond mouth corner. The tip exposed when mouth closed. Connecting tissue between the end of maxillary and mouth corner well developed, visible when mouth closed (Fig. 5C).

Lachrimal serrated in the lower and posterior edges. Serration of the lower edge limited in the posterior part of mouth corner. Lower edge of lachrimal slightly emarginate or nearly straight at mouth corner. Posterior edge narrow, the upper end not reaching to the anterior margin of eye.

Mouth terminal, with a prominent symphysial knob at tip of lower jaw. Upper lip not thick, bearing a row of primary teeth in the lower edge. Teeth minute and ciliform, difficult to observe by naked eye. Space between teeth narrow, nearly 


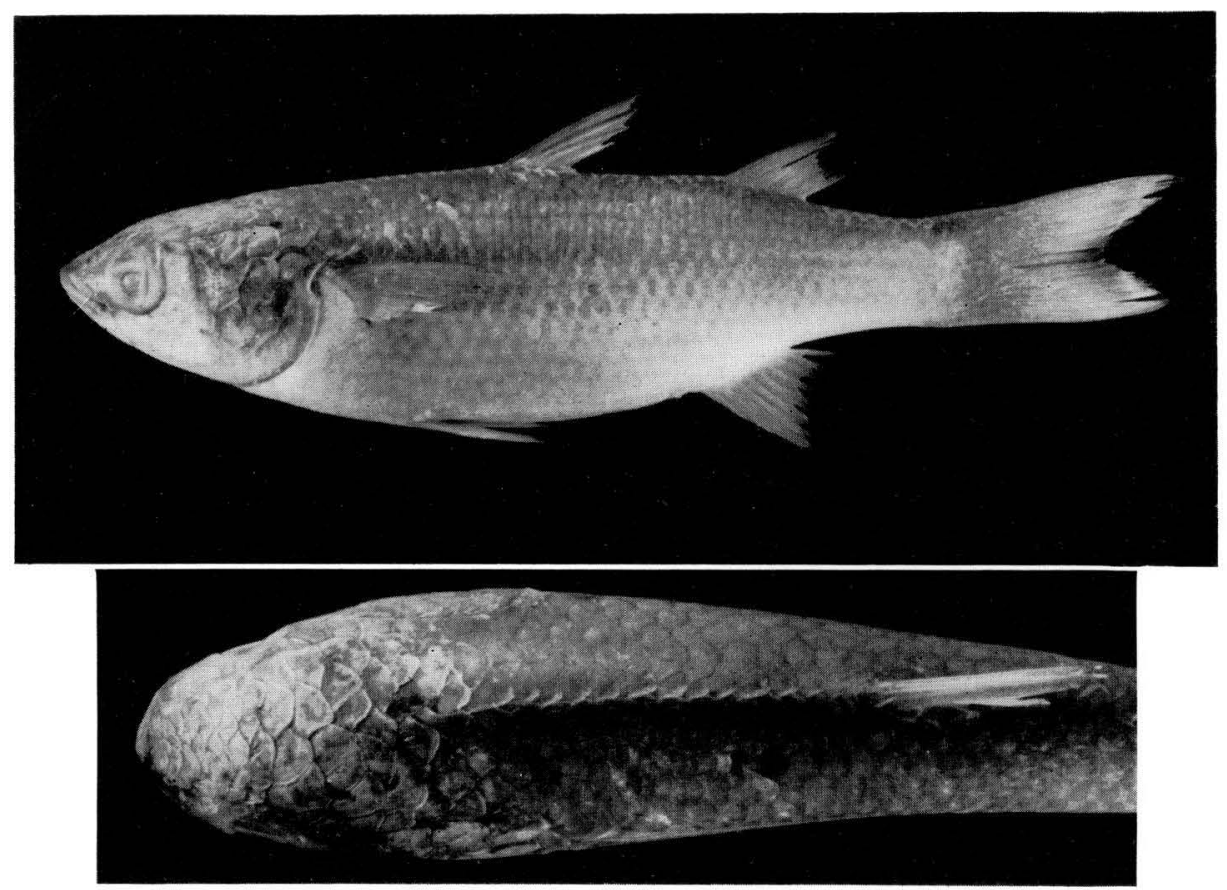

Fig. 3. Liza klunzingeri (Day). Upper, 124.0 mm SL, ZUMT 56073; lower, dorsal view of the same specimen.

same as the width of tooth. Individual tooth somewhat depressed at the tip with indistinct neck, the edge of tip round. A row of or irregularly arranged very minute secondary teeth sometimes observed. Lower lip forming thin edge, directed horizontally forward. Teeth on lower lip not observed. Mouth corner on a vertical line through posterior nostril.

Tongue with or without a longitudinal lower ridge of obtuse angle in front view. The ridge frequently indistinct or absent in larger specimens. The tip more or less free, sometimes adhering to mouth floor.

Ventral inner edges of right and left dentaries connected each other with a very short joint at the symphysis. The free space formed by the both edges of dentaries very wide at the just behind of the symphysis, the width gradually narrowing toward the posterior part of mandible.

Gill opening extending below between the posterior margins of pupil and eye. Gill rakers moderately long with two rows of minute fringes, the tips pointed. The longest raker on lower arch, its length 1.9-2.4 in the longest gill fillament.

Scales on body weakly ctenoid, relatively strong in the ventral part. Interorbital space and snout covered with weak ctenoid scales in the specimens from Pakistan, whereas with typical cycloid scales in that of the Arabian Gulf. The median scales on top of head reaching beyond anterior nostrils, the scales of anterior part minute. Lachrimal and mandible with minute scales. Second and third dorsal spines with 
a row of minute scales on their basal halves of outer edges. Second dorsal, outer surface of pectoral, inner surface of pelvic, anal and caudal fins also covered with minute scales. Most of the scales on the body with a simple and elongate sensory canal.

Stomach with well developed biconical gizzard. Each pyloric caecum with a simple tip.

Three predorsals, set between 2nd and 3rd, 4th and 5th, 6th and 7th vertebrae respectively. First pterygiophore of spinous dorsal fin set between 7 th and 8 th vertebrae. Posterior neural zygapophysis on 2 nd vertebra very long and slender, projecting postero-dorsally like antenna.

Color in preserved specimen: Dorsal grayish dark, lateral and ventral parts silvery. Body without any distinct marking, a few scale rows of midlateral part of trunk darkish. Dorsal fins darkish. Caudal fin margined black. Other fins pale. Basal part of the uppermost ray of pectoral fin black, but not forming a spot. Color of the fresh specimens from the Arabian Gulf was described by Kuronuma \& Abe (1986) who identified this species as L. macrolepis.

Distribution: Known from the coasts of Bombay and Karachi, and the inner Arabian Gulf (Persian Gulf).

Remarks. The species name "klunzingeri" was given by Day (1888a) to the description and figure of $M$. carinatus of Day (1876). Day's description of this species with one range in the number of lateral scale series and some proportional measurements indicates that the description was done on the basis of some plural specimens. Pillay (1962) examined three specimens of this species from Day's collection (ZSI 1398, 1399, and 1407) depositing at Zoological Survey of India, and stated that ZSI 1407 is Day's original of pl. 74, fig. 2. However, it is unknown whether the remaining two specimens were used for his description or not. Since Pillay also stated that these two specimens have no keel on the back, there is possibility that they are a different species. On the other hand, Whitehead \& Talwar (1976) stated that, in the possible type specimens of Day's species, the existent specimen of "klunzingeri=carinatus of Day (1876)" is only the figured ZSI 1407 from Bombay. In any case, ZSI 1407 must be regarded as one of syntypes of $M$. klunzingeri. We therefore designate this specimen as the lectotype.

Geographical variations are observed in this species. As mentioned above, the squamations on the interorbital space and snout are different between the specimens from the Arabian Gulf and Pakistan, viz. cycloid scale in the former, whereas ctenoid in the latter in the adult. The localities of this species are confined to the coast of delta zone of great river such as the Indus River in Pakistan and the TigrisEuphrates River system in the inner Arabian Gulf. This suggests that this species is an estuarine inhabitant, so its occurrence in the Gulf of Oman and the adjacent waters without such river seems unlikely. We consider that this variation is associated with geographical isolation.

See also the remarks of $L$. carinata. 


\title{
Liza affinis (Günther, 1861)
}

\author{
(Japanese name: Sesuji-bora)
}

(Fig. 4 and Fig. 5)

Mugil affinis Günther, 1861: 433, text fig. (type locality: Amoy, China); Schmidt, 1930: 27, fig. 1

(Itoman, Okinawa); Matsubara, 1955: 490 (key, reference), fig. 209; Senou \& Suzuki,

1980a: 58, pl. 3, fig. E. (Yaeyama I.); Suzuki et al., 1982: 19 (listed) (Yaeyama I.).

Mugil carinatus (not of Valenciennes): Oshima, 1919: 272 (Taiwan); Oshima, 1922: 247 (Taiwan); Harada, 1943: 72, pl. 22, fig. 87 (Hainan Is.); Mori, 1952: 81 (listed); Kamohara, 1954:

1 (Tosa); Chu et al., 1962 (part ?): 257 (fig. 214 is L. haematocheila) (South China Sea).

Myxus profugus Mohr, 1927: 184, fig. 6 (type locality: Japan and Formosa).

Liza haematocheila (not of Temminck \& Schlegel): Kamohara, 1957: 12, fig. 8 (Daikuma, AmamiOshima Is.); Suzuki, 1964: 158, fig. 1 (Amami-Oshima Is.).

Liza carinatus (not of Valenciennes): Chu et al., 1963: 198, fig. 155 (East China Sea); Song, 1981: 15, fig. 5 (China); Liang, 1986: 206, fig. 117 (Hainan Is.).

Liza affinis: Thomson, 1964: 3 (listed).

Liza carinata (not of Valenciennes); Kamohara \& Yamakawa, 1967: 2 (Okinawa); Senou \&

Suzuki, 1980b: 66, pl. 1, fig. F (Yaeyama I.); Suzuki et al., 1982: 19 (listed) (Yaeyama I.); Senou \& Kitamura, 1982: 38 (listed) (Wakayama).

Liza carinata carinata (not of Valenciennes): Yoshino \& Senou, 1984: 119, pl. 104, fig. I (Japan).

Materials examined: BMNH 1860. 7. 20. 11 (Holotype), 1 specimen, $149.9 \mathrm{~mm}$ in SL, Amoy, China. URM-P 1505, 1 specimen, 244.9, Mogi, Nagasaki Pref., Mar. 21, 1963. URM-P 1506, 1 specimen, 210.3, Mogi, Nagasaki Pref., Mar. 31, 1963. URM-P 5367, 15723-15724, 3 specimens, 186.3-233.6, Hizen Kashima fish market, Saga Pref., Oct. 21, $1982 . \quad$ URM-P 15689-15691,

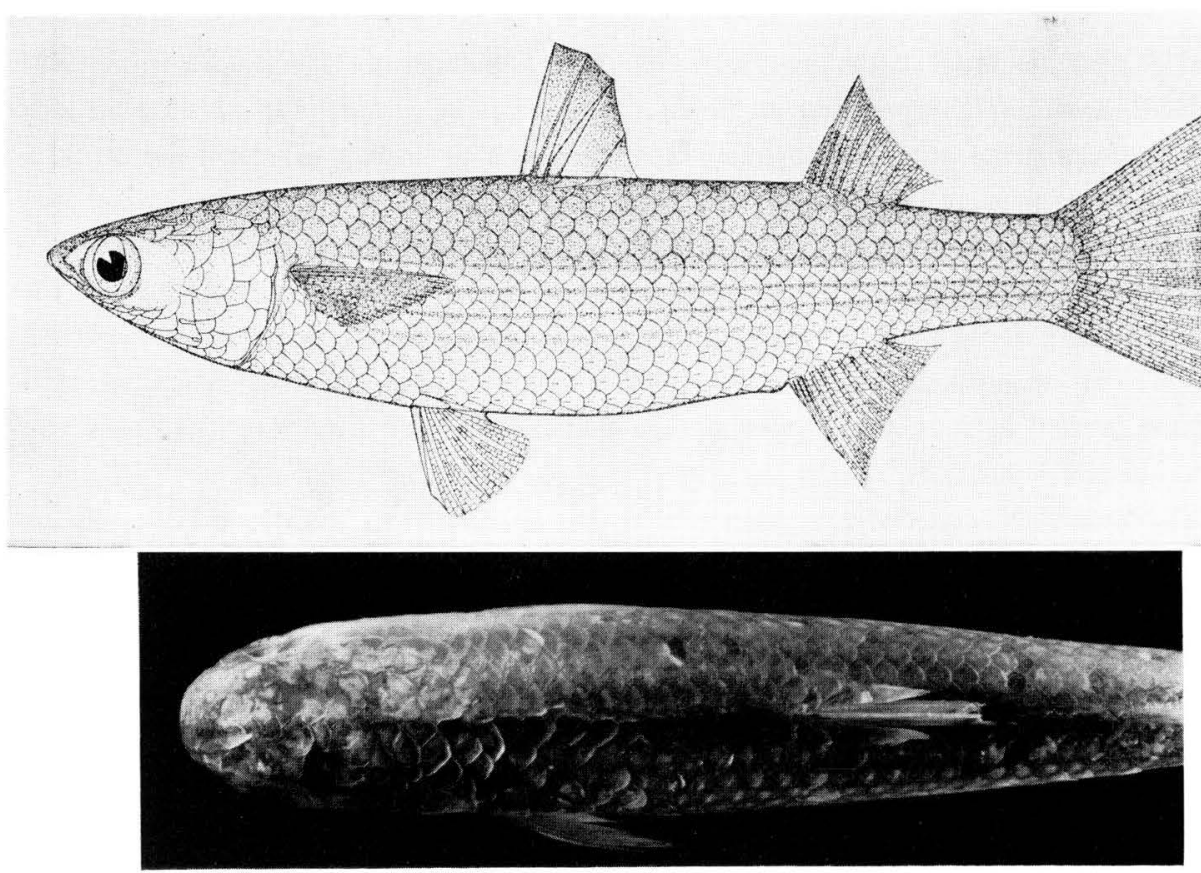

Fig. 4. Liza affinis (Günther). Upper, $168.0 \mathrm{~mm} \mathrm{SL}$, URM-P 15766, drawn by H. Senou; lower, dorsal view of URM-P 15705, $155.6 \mathrm{~mm}$ SL. 
15693-15696, 15698-15701, 15703-15705, 15707, 15709, 15711-15718, AMS-I 26276-001, WAM-P 28976-001, USNM 280252, ANSP 158681, 28 specimens, 119.7-199.9, Kamo Riv., Wakayama Pref., Jan. 20, 1981. URM-P 15719-15720, 2 specimens, 123.0-144.4, Hitotsuse Riv., Miyazaki Pref., Aug., 23, 1981. URM-P 15721-15722, 2 specimens, 136.2-156.1, Oyodo Riv., Miyazaki Pref., Aug. 24, 1981. URM-P 15725-15766, 42 specimens, 115.5-249.7, Nishimaizuru fish market, Kyoto Pref., Apr. 17, 1983. URM-P 16053-16069, 17 specimens, 54.0-96.2, Haneji-Okawa Riv., Okinawa Is., Apr. 29, 1982. URM-P 16070-16082, 13 specimens, 52.7-76.5, Taiho-Okawa Riv., Okinawa Is., Apr. 15, 1982. URM-P 16083-16086, 4 specimens, 63.1-83.1, Nagura Riv., Ishigaki Is., Yaeyama I., Sept. 3, 1982. YGM-P 2623, 1 specimen, 143.0, Shitafuki Riv., Ishigaki Is., Yaeyama I., Apr. 29, 1976. YCM-P 6248, 14 specimens, 93.8-156.7, Nagura Riv., Ishigaki Is., Yaeyama I., May 1, 1976. YCM-SSP 10503, 1 specimen, 136.2, Maera Riv., Iriomote Is., Yaeyama I., Mar. 30, 1974. YCM-SSP 10504-10506, 3 specimens, 110.0-135.9, Nagura Riv., Ishigaki Is., Yaeyama I., Jul. 9, 1980. YGM-SSP 10507-10508, 2 specimens, 125.4-128.6, Nakama Riv., Iriomote Is., Yaeyama I., Jul. 14, 1980. YCM-SSP 10509, 1 specimen, 101.1, Miyara Riv., Ishigaki Is., Yaeyama I., Oct. 25, 1981.

Description: Counts and proportional measurements are shown in Tables 1 and 2.

Body elongate, subcylindrical anteriorly, becoming compressed toward the tail. Middorsal line keeled in front of 1st dorsal fin, the keel forming sharp edge. In the specimens from the Ryukyu Islands, the keel frequently weak. The keel between 1st and 2nd dorsal fins absent or if present, usually very weak.

Head small, interorbital space slightly convex in front view. Adipose eyelid widely developed anteriorly and posteriorly, the posterior adipose eyelid thick. Posterior margin of adipose eyelid gap reaching between the posterior margin of pupil and the middle point between the posterior margins of pupil and eye.

Maxillary curved downward at mouth corner, the tip reaching beyond mouth corner. The tip exposed when mouth closed. Connecting tissue between the end of maxillary and mouth corner not developed, slightly visible (Fig. 5A) or invisible when mouth closed.

Lachrimal serrated in the lower and posterior edges. Serration of the lower edge starting from the anterior part of mouth corner. The lower edge of lachrimal emarginate at mouth corner. The posterior edge round and wide, the upper end reaching to the anterior edge of eye.

Mouth terminal, with a prominent symphysial knob at tip of lower jaw. Upper lip slightly thick, bearing a row of primary teeth in the lower edge. Teeth minute and ciliform, invisible by naked eye. Space between teeth narrow, nearly same as the width of tooth. The tip of tooth depressed, with neck. The edge of tip more or less round. A row of or irregularly arranged secondary teeth very minute with pointed tip, sometime observed. Lower lip forming thin edge, directed horizontally forward. Teeth on lower lip not observed. Mouth corner on a vertical line through anterior nostril in the specimens from the Ryukyu Islands, whereas between both nostrils or through anterior nostril in those from the mainland of Japan.

Tongue with a longitudinal lower ridge of right or obtuse angle in front view. The tip slightly free, rarely adhering to the mouth floor.

Ventral inner edges of right and left dentaries connected each other with a rela- 
tively long midlongitudinal joint at the symphysis. The free space formed by both edges of the dentaries relatively wide at the just behind of symphysis, and the width gradually narrowing toward the posterior part of mandible.

Gill opening extending below between the hind margins of pupil and eye, often a little behind or before each margin. Gill rakers relatively short with two rows of minute fringes, the tips round. The longest raker at corner of gill arches, its length 2.7-3.4 in the longest gill filament.

Scales on body weakly ctenoid, relatively strong in the ventral part. Interorbital space and snout covered with cycloid scales. The anterior scales minute, the median scales reaching beyond anterior nostrils. Lachrimal and mandible with minute scales. Second and third dorsal spines with a row of minute scales on their basal halves of outer edges. Outer surface of pectoral, inner surface of pelvic, 2nd

Table 1 a. Frequency distributions for certain meristic characters in Liza carinata complex. The numbers of lateral scale series indicated by plusses in L. klunzingeri of India, L. affinis of Taiwan and China were based on Day $(1876,1888 \mathrm{~b})$, Oshima (1919, 1922), Chu et al. (1963), Liang (1986) and Song (1981) respectively. The numbers with asterisk are those of type materials

\begin{tabular}{|c|c|c|c|c|c|c|c|c|c|c|c|c|c|c|c|c|c|}
\hline & \multicolumn{3}{|c|}{$\begin{array}{l}\text { Spinous dorsal } \\
\text { fin rays }\end{array}$} & \multicolumn{3}{|c|}{$\begin{array}{l}\text { Second dorsal } \\
\text { fin rays }\end{array}$} & \multicolumn{4}{|c|}{ Pectoral fin rays } & \multirow{2}{*}{\multicolumn{2}{|c|}{$\frac{\begin{array}{c}\text { Pelvic } \\
\text { fin rays }\end{array}}{\mathrm{I}, 5}$}} & \multirow{2}{*}{\multicolumn{5}{|c|}{$\frac{\text { Anal fin rays }}{\text { III,8 III,9 III,10 II,9 }}$}} \\
\hline & IV & $\mathrm{V}$ & & 8 & 9 & 10 & 15 & 16 & 17 & 18 & & & & & & & \\
\hline \multicolumn{18}{|l|}{ L. carinata } \\
\hline Red Sea & $28 *$ & 1 & & 1 & $28 *$ & & 1 & $18^{*}$ & 4 & 1 & 2 & & & $28 *$ & & & 1 \\
\hline \multicolumn{18}{|l|}{ L. klunzingeri } \\
\hline Pakistan & 10 & & & & 10 & & & 9 & 1 & & 1 & & & 10 & & & \\
\hline Arabian Gulf & 44 & & & & 44 & & 4 & 31 & 9 & & 4 & & & 44 & & & \\
\hline \multicolumn{18}{|l|}{ L. affinis } \\
\hline Honshu \& Kyushu & 78 & & & 5 & 66 & 6 & 1 & 25 & 47 & 5 & 7 & & 5 & 69 & 4 & 4 & \\
\hline Okinawa Is. & 30 & & & 2 & 27 & 1 & & 4 & 22 & 4 & 3 & & 1 & 29 & & & \\
\hline \multirow[t]{3}{*}{ Yaeyama I. } & 26 & & & 4 & 22 & & 1 & 5 & 14 & 6 & 2 & & 3 & 22 & & & \\
\hline & \multicolumn{3}{|c|}{$\begin{array}{c}\text { Branched caudal } \\
\text { fin rays }\end{array}$} & \multicolumn{14}{|c|}{ Lateral scale series } \\
\hline & $6+5$ & $6+6$ & $7+6$ & & 32 & 33 & 34 & 35 & 36 & 37 & 38 & 39 & 40 & 41 & 42 & 43 & \\
\hline \multicolumn{18}{|l|}{ L. carinata } \\
\hline Red Sea & & $29 *$ & & & & & & & 1 & 5 & $* 10$ & 7 & 2 & & & & \\
\hline \multicolumn{18}{|l|}{ L. klunzingeri } \\
\hline India & & & & & 1 & $*$ & + & + & + & & + & & & & & & \\
\hline Pakistan & & 10 & & & & & 1 & 3 & 4 & 1 & 1 & & & & & & \\
\hline Arabian Gulf & & 42 & 2 & & 1 & 3 & 6 & 13 & 13 & 3 & 1 & & & & & & \\
\hline \multicolumn{18}{|l|}{ L. affins } \\
\hline Honshu \& Kyushu & 1 & 77 & & & & & & 2 & 10 & 12 & 22 & 15 & 14 & 0 & 0 & 1 & \\
\hline Okinawa Is. & & 29 & & & & & 1 & 3 & 10 & 9 & 6 & 1 & & & & & \\
\hline Yaeyama I. & & 26 & & & & 2 & 5 & 9 & 7 & 2 & 1 & & & & & & \\
\hline Taiwan & & & & & & & & & & & + & + & + & & & & \\
\hline China & & & & & & & & & + & + & + & $+1 *$ & $*+$ & + & + & + & \\
\hline
\end{tabular}


Table $1 \mathrm{~b}$.

\begin{tabular}{|c|c|c|c|c|c|c|c|c|c|c|c|}
\hline & \multicolumn{3}{|c|}{$\begin{array}{l}\text { Transverse scale } \\
\text { rows }\end{array}$} & \multicolumn{4}{|c|}{$\begin{array}{l}\text { Cheek scale } \\
\text { rows }\end{array}$} & \multicolumn{3}{|c|}{$\begin{array}{l}\text { No. of pyloric } \\
\text { caeca }\end{array}$} & \multirow{2}{*}{$\begin{array}{c}\text { Vertebral counts } \\
11+13=24\end{array}$} \\
\hline & 11 & 12 & 13 & 3 & 4 & 5 & 5 & 4 & 5 & 6 & \\
\hline \multicolumn{12}{|l|}{ L. carinata } \\
\hline Red Sea & & 7 & $18 *$ & & $24 *$ & & & & 8 & & $28 *$ \\
\hline \multicolumn{12}{|l|}{ L. klunzingeri } \\
\hline Pakistan & & 1 & 9 & & 10 & & & & 5 & & 10 \\
\hline Arabian Gulf & & 5 & 36 & & 43 & 1 & & & 11 & & 44 \\
\hline \multicolumn{12}{|l|}{ L. affinis } \\
\hline Honshu \& Kyushu & 6 & 35 & 38 & 8 & 71 & & & 2 & 28 & 2 & 14 \\
\hline Okinawa Is. & 7 & 23 & & 1 & 29 & & & & & & \\
\hline \multirow[t]{3}{*}{ Yaeyama I. } & 8 & 16 & & & 26 & & & 1 & 17 & 1 & 7 \\
\hline & \multicolumn{11}{|c|}{ Number of gill rakers: The means and standard deviations in parentheses. } \\
\hline & $\mathrm{N}: \mathrm{S}$ & $\begin{array}{l}\mathrm{RANC} \\
\mathrm{L} \mathrm{mm}\end{array}$ & & UPPEI & G. 1 & R. & & LOW & ER G. & $\mathrm{R}$. & TOTAL G. R. \\
\hline \multicolumn{12}{|l|}{ L. carinata } \\
\hline Red Sea & \multicolumn{3}{|c|}{ 18: $\quad 66.9-124.1$} & \multirow{2}{*}{\multicolumn{6}{|c|}{$25-35(29.9,3.0)+44-59(51.2$}} & \multicolumn{2}{|c|}{$4.2)=69-93(81.1,7.1)$} \\
\hline \multicolumn{6}{|l|}{ L. Klunzingeri } & & & & & & \\
\hline Pakistan & \multicolumn{3}{|c|}{$5: 119.5-133.8$} & \multicolumn{3}{|c|}{$34-38(36.0,1.6)$} & \multirow{2}{*}{\multicolumn{3}{|c|}{$\begin{array}{r}+60-68(64.0 \\
+\quad 51-69(58.9\end{array}$}} & \multicolumn{2}{|c|}{$3.5)=94-105(100.0,4.9)$} \\
\hline Arabian Gulf & \multicolumn{3}{|c|}{ 19: $66.3-138.6$} & \multicolumn{3}{|c|}{$28-40(33.8,3.7)$} & & & & \multicolumn{2}{|c|}{$5.3)=79-109(92.7,8.9)$} \\
\hline \multicolumn{12}{|l|}{ L. affinis } \\
\hline Honshu \& Kyushu & \multicolumn{3}{|c|}{ 1 $32: 123.7-249.7$} & \multicolumn{3}{|c|}{$29-42(37.2,3.2)$} & + & $44-60$ & 51.7 & \multicolumn{2}{|c|}{$3.0)=73-102(88.9,5.8)$} \\
\hline Yaeyama I. & \multicolumn{3}{|c|}{$19: 111.0-156.7$} & \multicolumn{4}{|c|}{$27-42(35.2,3.4)$} & \multicolumn{2}{|c|}{$-45-55(49.2$} & \multicolumn{2}{|c|}{$2.2)=75-94(84.4,4.8)$} \\
\hline
\end{tabular}

dorsal, anal and caudal fins also covered with minute scales. Most of the scales on the body with a simple and elongate sensory canal.

Stomach with well developed biconical gizzard. Each pyloric caecum with a simple tip.

Three predorsals, set between 2 nd and 3rd, 4 th and 5 th, 5 th and 6 th vertebrae respectively. First pterygiophore of spinous dorsal fin set between 6 th and 7 th vertebrae. Posterior neural zygapophysis on 2nd vertebra very long and slender, projecting postero-dorsally like antenna.

Color when fresh: Body bluish or greenish dark in the back, silvery in the lateral and ventral side. Several longitudinal dark stripes along the scale rows on the middle part of trunk. Upper portion of iris orange. Spinous and second dorsal fins darkish. Caudal fin with relatively broad dark margin, its basal part also darkish, but the middle part pale. Anal fin partially darkish. Pelvic fin white. Pectoral fin somewhat darkish, the basal part of the uppermost ray black, but not forming a distinct spot. In the specimens from the Ryukyu Islands, the color generally paler than that of the mainland of Japan.

Distribution: Known from Japan except the northern part of Hokkaido, through the Ryukyu Islands, to Taiwan, and the coasts from Shanghai to Peihai (Gulf of 
Table 2 a. Proportional measurements as the percent of standard length in Liza carinata complex. Data show ranges: the means, standard deviations and sample sizes are in parentheses.

\begin{tabular}{|c|c|c|c|}
\hline & \multicolumn{3}{|c|}{ L. carinata } \\
\hline & \multicolumn{3}{|c|}{ Red Sea } \\
\hline & Lectotype & Paralectotype & Total specimens \\
\hline Number of specimens (N) & 1 & 1 & 25 \\
\hline Standard length (SL) (mm) & 86.9 & 80.0 & $66.9-124.1$ \\
\hline Total length (TL) & -- & - & $125.6-128.1(127.0,0.9, \quad 8)$ \\
\hline Fork length (FL) & - & 116.0 & $113.8-117.8(115.6,1.0,19)$ \\
\hline Prefirst dorsal fin length (PrD1L) & 51.8 & 52.9 & $48.1-52.9(50.4,1.3,25)$ \\
\hline Presecond dorsal fin length (PrD2L) & 76.6 & 77.1 & $73.4-77.5(75.3,1.3,25)$ \\
\hline Postfirst dorsal fin length (PoD1L) & 52.8 & 52.0 & $50.9-55.1(53.0,1.1,25)$ \\
\hline Prepectoral fin length (PrPL) & 32.2 & 31.9 & $28.6-32.2(30.3,1.0,25)$ \\
\hline Prepelvic fin length (PrVL) & 42.1 & 42.6 & $39.7-43.8(41.3,1.0,24)$ \\
\hline Preanal fin length (PrAL) & 75.3 & 75.1 & $69.6-75.3(72.5,1.6,25)$ \\
\hline Preanus length (PrAnL) & 72.0 & 71.8 & $66.7-72.3(69.2,1.6,25)$ \\
\hline Caudal peduncle length (GPL) & 19.7 & 17.9 & $17.6-21.0(19.5,1.0,25)$ \\
\hline $\begin{array}{l}\text { Distance between 1st and 2nd dorsal } \\
\text { fins (D1-D2) }\end{array}$ & 26.5 & 25.8 & $24.3-28.3(26.3,1.0,25)$ \\
\hline Head length (HL) & 29.9 & 29.9 & $27.3-30.4(28.9,0.8,25)$ \\
\hline Snout length (SnL) & 7.1 & 7.5 & $6.4 \quad 7.7(7.1,0.3,25)$ \\
\hline Postorbital length $(\mathrm{POH})$ & 16.0 & 15.6 & $14.4-16.5(15.4,0.5,25)$ \\
\hline Eye diameter (ED) & 8.2 & 8.3 & $7.2-9.0(7.9,0.4,25)$ \\
\hline Adipose eyelid length (AEL) & 15.8 & 14.4 & $14.1-17.5(15.5,0.9,25)$ \\
\hline Preadipose eyelid length (PrAEL) & 3.3 & 3.3 & $2.5-\quad 4.2(3.3,0.4,25)$ \\
\hline Postadipuse eyelid length (PoAEL) & 6.4 & 5.4 & $5.4-9.3(\quad 7.4,0.9,25)$ \\
\hline Adipose eyelid gap (AEG) & 5.9 & 6.1 & $4.2-\quad 6.7(5.0,0.7,25)$ \\
\hline Interorbital width (IW) & 9.2 & 9.3 & $8.2-9.6(9.1,0.4,25)$ \\
\hline Thickness at pectoral fins (ThP) & 15.7 & 16.8 & $14.5-17.3(16.1,0.7,25)$ \\
\hline Thickness at first dorsal fin (ThD1) & 11.2 & 12.0 & $10.8-15.5(12.6,1.0,25)$ \\
\hline Thickness at second dorsal fin (ThD2) & 7.2 & 7.5 & $6.4 \quad 8.8(7.7,0.7,25)$ \\
\hline $\begin{array}{l}\text { Distance between anterior and posteri- } \\
\text { or nostrils (AN-PN) }\end{array}$ & 1.4 & 1.4 & $1.4,0.1,25)$ \\
\hline Width of mouth (WM) & 10.4 & 10.1 & $9.8,0.5,24)$ \\
\hline Thickness of upper lip (ThUL) & 1.7 & 1.8 & $1.8,0.2,25)$ \\
\hline Lower jaw length (LJL) & 6.7 & 6.5 & $5.0-6.9(6.3,0.4,25)$ \\
\hline Angle of lower jaw (ALJ) $\left({ }^{\circ}\right)$ & 101.8 & 102.3 & $92.7-123.1(102.2,6.9,24)$ \\
\hline Depth at mouth corner (DM) & 7.5 & 8.0 & $6.4 \quad 9.0(8.0,0.6,25)$ \\
\hline Depth at eye (DE) & 16.6 & 16.0 & $14.9-16.6(15.8,0.5,25)$ \\
\hline Depth at pectoral fin (DP) & 23.2 & 24.9 & $21.0-24.9(22.9,1.1,23)$ \\
\hline Depth at first dorsal fin (DD1) & 25.7 & 28.1 & $24.0-29.4(26.1,1.6,23)$ \\
\hline Depth at anal fin (DA) & 21.4 & 23.0 & $19.6-23.7(21.8,0.9,25)$ \\
\hline Caudal peduncle depth (CPD) & 10.6 & 11.1 & $10.0-12.0(10.8,0.5,25)$ \\
\hline Pectoral fin length (PFL) & 20.6 & 22.1 & $19.8-23.6(21.7,1.0,24)$ \\
\hline Pectoral fin base length (PFB) & 6.0 & 5.9 & $4.7-\quad 6.3(5.8,0.3,24)$ \\
\hline Axillary scale length (ASL) & 5.1 & 6.8 & $4.3-8.0(6.0,0.9,25)$ \\
\hline First dorsal spine length (1stDS) & 16.8 & 19.4 & $15.8-19.7(17.3,1.1,21)$ \\
\hline Second dorsal spine length (2ndDS) & 15.7 & 17.6 & $14.9-18.3(16.2,0.9,21)$ \\
\hline Third dorsal spine length (3rdDS) & 13.3 & 14.4 & $13.0-15.8(14.4,0.9,23)$ \\
\hline Forth dorsal spine length (4thDS) & 4.9 & 7.3 & $4.9-\quad 8.5(\quad 6.9,0.9,22)$ \\
\hline First dorsal fin base length (D1B) & 6.8 & 6.9 & $6.0-\quad 7.8(\quad 7.0,0.4,24)$ \\
\hline Dorsal obbasal scale length (DOS) & 12.0 & 13.1 & $9.6-14.3(12.2,1.0,20)$ \\
\hline Second dorsal fin height $(\mathrm{D} 2 \mathrm{H})$ & - & - & $13.4-15.3(14.4,0.7,10)$ \\
\hline Second dorsal fin base length (D2B) & 9.4 & 9.4 & $8.8-10.7(9.8,0.5,25)$ \\
\hline Pelvic fin length (VFL) & 14.7 & 16.9 & $14.7-17.7(16.2,0.7,25)$ \\
\hline Pelvic obbasal scale length (VOS) & 9.6 & 9.6 & $5.0-\quad 9.7(8.4,1.1,23)$ \\
\hline Interpelvic flange length (IFL) & 10.2 & 10.8 & $9.3-11.7(10.3,0.7,21)$ \\
\hline Anal fin height $(\mathrm{AH})$ & 13.3 & 15.5 & $13.3-16.1(15.1,1.0,13)$ \\
\hline Anal fin base length $(\mathrm{AB})$ & 9.4 & 10.8 & $9.4-11.8(10.8,0.6,25)$ \\
\hline
\end{tabular}


Table $2 \mathrm{~b}$.

\begin{tabular}{|c|c|c|c|}
\hline & \multicolumn{3}{|c|}{ L. klunzingeri } \\
\hline & \multirow{2}{*}{$\frac{\text { India }}{\text { Lectotype }}$} & \multirow[t]{2}{*}{ Pakistan } & Arabian Gulf \\
\hline & & & \\
\hline$N$ & 1 & 10 & 44 \\
\hline SL & 102.1 & $119.5-133.8$ & $66.3-142.0$ \\
\hline TL & - & $126.1-129.5(127.6,1.0,10)$ & $124.9-129.6(127.0,1.3,30)$ \\
\hline FL & - & $115.1-117.3(116.4,0.6,10)$ & $114.9-119.5(117.0,1.0,40)$ \\
\hline PrDIL & 53.7 & $50.3-52.8(51.4,0.8,10)$ & $49.0-54.6(52.1,1.1,43)$ \\
\hline $\operatorname{PrD} 2 \mathrm{~L}$ & - & $73.8-75.9(75.1,0.7,10)$ & $74.1-77.5(75.8,0.8,43)$ \\
\hline PoD1L & - & $50.5-52.3(51.5,0.7,10)$ & $48.8-54.1(51.7,1.2,43)$ \\
\hline $\operatorname{PrPL}$ & - & $30.4-31.9(31.2,0.4,10)$ & $28.1-31.8(30.1,1.0,43)$ \\
\hline PrVL & - & $39.4-42.2(41.0,0.9,10)$ & $38.4-43.2(41.0,1.2,42)$ \\
\hline PrAL & - & $70.5-73.9(72.4,1.2,10)$ & $69.1-75.1(72.4,1.2,43)$ \\
\hline $\operatorname{PrAnL}$ & - & $67.1-70.4(69.0,1.1,10)$ & $66.5-72.2(69.1,1.2,42)$ \\
\hline CPL & - & $19.6-20.9(20.3,0.6,10)$ & $18.3-21.5(20.0,0.7,42)$ \\
\hline $\mathrm{D} 1-\mathrm{D} 2$ & - & $23.4-26.2(24.6,0.9,10)$ & $22.8-26.9(25.2,1.0,43)$ \\
\hline $\mathrm{HL}$ & 31.3 & $28.9-31.0(29.9,0.7,10)$ & $27.0-30.7(29.2,1.0,43)$ \\
\hline $\mathrm{SnL}$ & - & $7.3-8.1(7.7,0.2,10)$ & $6.7-8.0(7.4,0.3,43)$ \\
\hline $\mathrm{POH}$ & - & $15.3-17.3(16.2,0.6,10)$ & $14.1-16.9(15.6,0.7,43)$ \\
\hline $\mathrm{ED}$ & - & $7.1-8.0(7.5,0.3,10)$ & $7.0-\quad 8.5(7.7,0.4,43)$ \\
\hline AEL & - & $13.9-16.1(15.1,0.8,10)$ & $12.5-16.9(14.9,0.8,43)$ \\
\hline PrAEL & - & $3.2-4.0(3.6,0.3,10)$ & $2.7-\quad 4.1(3.5,0.3,43)$ \\
\hline POAEL & - & $7.2,0.7,10)$ & $5.0-8.6(\quad 7.1,0.7,43)$ \\
\hline $\mathrm{AEG}$ & - & $3.9-\quad 5.0(4.4,0.4,10)$ & $3.5-\quad 5.7(4.6,0.4,43)$ \\
\hline IW & - & $9.3-10.0(9.6,0.2,10)$ & $8.4-10.0(9.3,0.4,43)$ \\
\hline ThP & - & $16.3-18.1(17.2,0.6,10)$ & $16.0-18.5(17.4,0.7,43)$ \\
\hline ThD1 & 一 & $11.8-14.3(13.3,0.8,10)$ & $11.6-15.7(14.3,0.9,42)$ \\
\hline ThD2 & - & $7.7-9.2(\quad 8.5,0.6,10)$ & $7.5-10.3(9.0,0.6,43)$ \\
\hline AN-PN & - & $1.0-1.5(1.3,0.1,10)$ & $1.1-1.6(1.3,0.2,43)$ \\
\hline WM & $\ldots$ & $9.1-10.5(9.8,0.4,10)$ & $8.9-11.5(10.1,0.6,41)$ \\
\hline ThUL & - & $1.5-2.0(1.8,0.1,10)$ & $1.4-2.3(1.9,0.2,43)$ \\
\hline LJL & $\ldots$ & $6.2-7.4(\quad 6.8,0.4,10)$ & $5.9-\quad 7.8(\quad 6.7,0.4,43)$ \\
\hline $\mathrm{ALJ}$ & - & $84.2-112.1(93.4,8.1,10)$ & $87.6-112.9(99.6,6.5,41)$ \\
\hline $\mathrm{DM}$ & - & $7.8-9.8(8.4,0.6,10)$ & $7.1-9.1(8.2,0.5,43)$ \\
\hline $\mathrm{DE}$ & - & $15.3-17.1(16.2,0.6,10)$ & $14.6-17.1(15.7,0.6,43)$ \\
\hline $\mathrm{DP}$ & - & $22.5-26.2(24.0,1.0,10)$ & $21.6-27.1(24.8,1.5,41)$ \\
\hline DD1 & - & $26.2-29.4(27.3,1.0,10)$ & $23.9-31.4(28.7,2.0,38)$ \\
\hline $\mathrm{DA}$ & - & $22.1-24.8(23.1,0.9,10)$ & $21.2-25.5(23.8,1.0,43)$ \\
\hline CPD & - & $11.1-12.3(11.7,0.4,10)$ & $10.9-12.3(11.6,0.4,43)$ \\
\hline PFL & - & $20.6-22.7(21.9,0.7,10)$ & $20.0-23.9(21.8,0.9,42)$ \\
\hline PFB & - & $5.9-6.5(6.3,0.2,10)$ & $5.3-6.4(6.0,0.2,43)$ \\
\hline ASL & - & $4.3-7.1(5.4,0.9,10)$ & $3.8-\quad 6.4(\quad 5.2,0.6,39)$ \\
\hline 1 stDS & - & $16.0-17.9(16.8,0.8,9)$ & $13.7-21.3(16.5,1.3,38)$ \\
\hline $2 \mathrm{ndDS}$ & - & $14.5-16.9(15.7,0.7,10)$ & $13.2-20.6(15.7,1.3,41)$ \\
\hline $3 \mathrm{rdDS}$ & $\ldots$ & $12.6-14.5(13.7,0.6,10)$ & $11.8-18.5(14.1,1.1,42)$ \\
\hline 4thDS & - & $6.2-8.2(7.1,0.6,10)$ & $5.2-10.9(7.3,1.1,43)$ \\
\hline $\mathrm{D} 1 \mathrm{~B}$ & - & $6.3-7.3(6.8,0.3,10)$ & $5.7-\quad 7.8(\quad 6.8,0.5,43)$ \\
\hline DOS & - & $8.5-15.1(12.3,1.6,10)$ & $6.3-15.3(12.5,1.4,43)$ \\
\hline $\mathrm{D} 2 \mathrm{H}$ & - & $13.5-15.8(14.7,0.6,10)$ & $13.1-17.8(15.4,0.8,41)$ \\
\hline D2B & - & $8.8-10.4(9.7,0.5,10)$ & $8.8-10.6(9.7,0.4,43)$ \\
\hline VFL & - & $15.5-17.1(16.1,0.5,10)$ & $14.6-18.5(16.4,0.8,42)$ \\
\hline VOS & - & $7.1-10.2(8.5,1.1,10)$ & $7.1-10.4(\quad 8.5,0.8,43)$ \\
\hline IFL & $\ldots$ & $7.8-10.5(9.3,0.8,9)$ & $8.2-11.3(9.9,0.7,37)$ \\
\hline $\mathrm{AH}$ & $\ldots$ & $14.9-16.2(15.7,0.5,9)$ & $14.4-19.5(17.0,1.0,38)$ \\
\hline $\mathrm{AB}$ & - & $10.1-12.1(11.2,0.6,10)$ & $9.9-12.6(11.3,0.6,42)$ \\
\hline
\end{tabular}


Table $2 \mathrm{c}$.

\begin{tabular}{|c|c|c|c|}
\hline & \multicolumn{3}{|c|}{ L. affinis } \\
\hline & China & Honshu \& Kyushu & Yaeyama Islands \\
\hline & Holotype & & \\
\hline $\mathrm{N}$ & 1 & 77 & 19 \\
\hline SL & 149.9 & $115.5-249.7$ & $111.0-156.7$ \\
\hline TL & $\ldots$ & $120.8-125.3(123.4,1.1,74)$ & $121.5-125.6(123.9,1.0,19)$ \\
\hline FL & - & $112.4-115.9(114.2,0.8,76)$ & $113.6-116.7(114.8,0.7,19)$ \\
\hline PrDIL & 47.4 & $45.3-49.5(46.9,1.0,76)$ & $48.2-52.0(49.7,1.1,19)$ \\
\hline PrD2L & - & $71.4-76.4(73.9,1.0,75)$ & $75.9-78.2(77.0,0.7,19)$ \\
\hline PoD1L & 一 & $52.8-57.3(55.2,1.1,76)$ & $50.3-54.5(52.6,1.0,19)$ \\
\hline PrPL & - & $23.3-27.6(25.5,1.0,76)$ & $26.0-28.6(26.9,0.9,19)$ \\
\hline PrVL, & - & $36.0-41.3(38.1,1.1,76)$ & $38.9-43.5(40.4,1.2,19)$ \\
\hline $\operatorname{PrAL}$ & - & $69.8-75.3(72.3,1.3,76)$ & $73.8-76.9(75.4,0.8,19)$ \\
\hline PrAnL & 一 & $66.2-71.9(69.3,1.2,73)$ & $69.8-73.0(71.6,0.9,19)$ \\
\hline CPL & - & $17.9-22.3(20.1,0.8,76)$ & $17.5-20.6(18.8,0.7,19)$ \\
\hline $\mathrm{D} 1-\mathrm{D} 2$ & $\longrightarrow$ & $25.8-30.5(27.6,0.9,76)$ & $25.7-29.4(27.8,0.9,19)$ \\
\hline $\mathrm{HL}$ & 一 & $22.1-26.3(24.1,1.0,76)$ & $24.0-26.9(25.4,0.9,19)$ \\
\hline $\mathrm{SnL}$ & - & $5.6-\quad 7.2(6.4,0.3,76)$ & $6.0-6.9(6.5,0.3,19)$ \\
\hline $\mathrm{POH}$ & - & $11.4-13.5(12.6,0.5,76)$ & $11.7-13.6(12.6,0.5,19)$ \\
\hline ED & - & $5.3-\quad 7.3(\quad 6.2,0.4,76)$ & $6.9-8.0(7.3,0.3,19)$ \\
\hline AEL & - & $11.3-14.9(12.9,0.8,76)$ & $12.9-15.2(14.1,0.8,6)$ \\
\hline PrAEL & - & $2.7-3.9(3.3,0.3,76)$ & $3.2-\quad 3.4(\quad 3.3,0.1$ \\
\hline PoAEL & - & $4.8-\quad 7.5(\quad 6.2,0.6,76)$ & $5.1-\quad 7.1(6.2,0.7,6)$ \\
\hline $\mathrm{AEG}$ & - & $2.8-5.1(3.6,0.5,76)$ & $4.5-5.6(5.1,0.4,6)$ \\
\hline IW & - & $6.9-\quad 9.5(\quad 7.9,0.5,76)$ & $7.8-9.1(8.5,0.3,19)$ \\
\hline ThP & - & $13.9-17.6(15.2,0.6,76)$ & $15.1-17.4(16.1,0.8,19)$ \\
\hline ThDI & - & $11.5-16.8(14.2,1.1,74)$ & $12.5-17.6(14.8,1.6,15)$ \\
\hline $\mathrm{ThD} 2$ & - & $8.0-11.1(9.5,0.6,75)$ & $8.4-10.6(9.4,0.8,17)$ \\
\hline AN-PN & - & $0.8-1.5(1.2,0.1,76)$ & $1.1-1.7(1.4,0.2,19)$ \\
\hline WM & 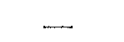 & $7.1-9.3(8.0,0.4,76)$ & $8.4-\quad 9.6(\quad 8.9,0.3,15)$ \\
\hline ThUL, & - & $1.0-2.0(1.6,0.2,74)$ & $1.8-2.6(2.1,0.2,19)$ \\
\hline LJL & - & $4.2-\quad 5.4(\quad 4.8,0.3,75)$ & $4.7-5.4(5.1,0.2,19)$ \\
\hline $\mathrm{ALJ}$ & - & $102.4-127.3(114.0,5.8,77)$ & $110.5-130.8(121.7,6.1,15)$ \\
\hline DM & - & $5.3-6.7(6.0,0.4,75)$ & $5.7-6.8(6.3,0.3,16)$ \\
\hline $\mathrm{DE}$ & - & $11.6-14.5(12.8,0.6,75)$ & $13.0-15.0(13.9,0.6,17)$ \\
\hline DP & - & $17.5-22.1(19.1,0.9,75)$ & $17.7-21.6(19.9,1.1,18)$ \\
\hline DD1 & - & $19.0-26.8(22.2,1.7,75)$ & $20.7-26.7(23.0,1.5,16)$ \\
\hline $\mathrm{DA}$ & - & $17.6-21.3(19.3,0.9,76)$ & $19.1-21.9(20.5,0.7,19)$ \\
\hline CPD & - & $9.3-11.2(10.2,0.4,76)$ & $10.0-11.6(10.8,0.4,19)$ \\
\hline PFL & - & $14.5-18.2(16.4,0.8,76)$ & $16.7-18.4(17.7,0.6,19)$ \\
\hline PFB & - & $4.4-\quad 5.6(4.9,0.2,76)$ & $4.8-\quad 5.5(\quad 5.1,0.2,19)$ \\
\hline ASL & - & $3.8-7.9(\quad 6.0,0.8,74)$ & $4.4-6.9(5.8,0.7,18)$ \\
\hline $1 \mathrm{stDS}$ & - & $10.5-17.2(13.4,1.2,72)$ & $13.7-16.4(14.7,0.7,19)$ \\
\hline 2ndDs & - & $11.3-16.4(13.6,1.1,75)$ & $13.2-15.3(14.2,0.6,18)$ \\
\hline 3rdDS & - & $10.4-14.1(12.1,1.0,74)$ & $11.4-13.6(12.4,0.7,18)$ \\
\hline 4thDS & - & $4.1-\quad 7.5(\quad 5.9,0.7,76)$ & $5.0-\quad 6.8(\quad 6.1,0.5,18)$ \\
\hline $\mathrm{D} 1 \mathrm{~B}$ & - & $5.3-\quad 7.1(\quad 6.1,0.4,76)$ & $5.4-6.7(\quad 6.1,0.4,19)$ \\
\hline DOS & - & $7.6-11.9(10.2,1.0,76)$ & $9.6-12.3(10.7,0.7,18)$ \\
\hline $\mathrm{D} 2 \mathrm{H}$ & $\longrightarrow$ & $11.4-15.1(13.0,0.8,75)$ & $11.5-14.0(13.0,0.6,18)$ \\
\hline $\mathrm{D} 2 \mathrm{~B}$ & - & $9.1-11.5(9.7,0.5,76)$ & $8.0-9.3(\quad 8.6,0.4,19)$ \\
\hline VLF & 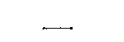 & $12.0-15.4(13.7,0.7,76)$ & $12.5-15.9(14.3,0.7,19)$ \\
\hline VOS & - & $5.3-\quad 8.3(7.1,0.8,76)$ & $6.1-\quad 8.5(\quad 7.6,0.7,19)$ \\
\hline IFL & - & $7.0-10.2(8.0,0.7,73)$ & $7.6-9.5(8.4,0.5,19)$ \\
\hline $\mathrm{AH}$ & $\longrightarrow$ & $11.9-15.0(13.3,0.8,73)$ & $12.7-14.5(13.7,0.6,19)$ \\
\hline $\mathrm{AB}$ & - & $9.4-11.7(10.6,0.5,76)$ & $9.0-10.8(9.7,0.6,19)$ \\
\hline
\end{tabular}


Tongking) and Hainan Island. No record from the Yellow Sea. Although Mori (1952) listed this species from Pusan, Korea, there is no recent record from Korea (Dr. S.-R. Jeon pers. com.).

Remarks. This fish have been hitherto identified as $M$. carinatus or $L$. carinata since Oshima $(1919,1922)$ by ichthyologists of the Far East. During a visit to the British Museum (Natural History), the second author (T. Y.) found that the holotype of $M$. affinis is identical with above mentioned fish. This species is easily distinguished from $L$. carinata and $L$. klunzingeri in its short pectoral fin, small head and undeveloped connecting tissue between the end of maxillary and the mouth corner (see key and Fig. 5).
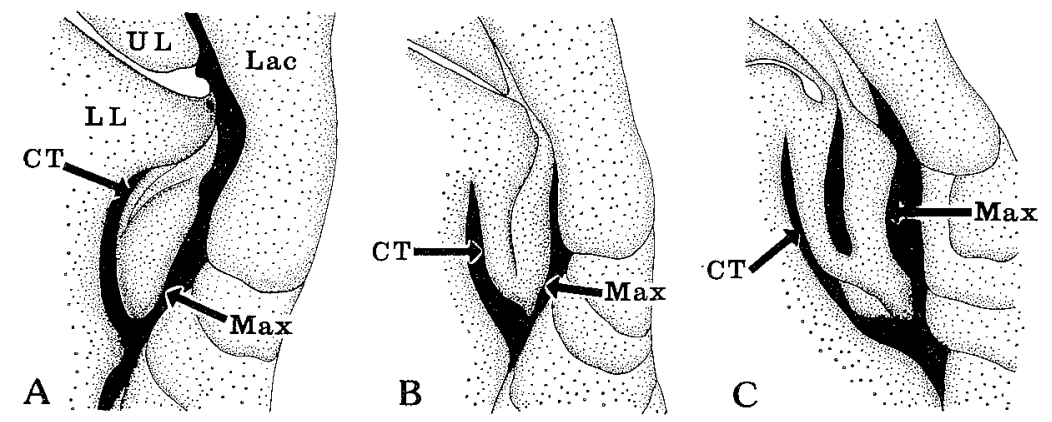

Fig. 5. Left mouth corner in three keeled back mullets. A, L. affinis, $128.0 \mathrm{~mm}$ SL, YGM-P 6248; B, L. carinata, $121.4 \mathrm{~mm}$ SL, MNHN 1966 443; C, L. klunzingeri, $135.5 \mathrm{~mm}$ SL, MTUF 20439. CT, Connecting tissue between mouth corner and the end of maxillary; Lac, lachrimal; LL, lower lip; Max, maxillary; UL, upper lip. Serration of lachrimal is omitted.

Geographical variations are observed in this species. The number of lateral scale series of the specimens from the Yaeyama I. and Okinawa Is. tends to be relatively fewer than that of the other region including Taiwan where is very close to Yaeyama I. (Table 1). As mentioned above, the specimens from the Ryukyu I. are also somewhat different in the other features such as the developmental condition of a keel on the back, the position of mouth corner and the coloration. These differencies suggest that the populations of Yaeyama I. and Okinawa Is., at least, are isolated from those of Taiwan and the mainland of Japan in spite of the immediate localities.

This species inhabits bay or estuaries such as tidal influenced zone of river and the adjacent coastal waters near river mouth in the mainland of Japan. In the Ryukyu I., this fish is only found in the river estuaries, since coral reefs develop in the other areas.

\section{Acknowledgments}

We are grateful to Dr. Susan E. Ingham (Victoria, Australia) for her valuable advice and information on the taxonomy of mugilids. We wish to express our gratitude to the following persons for 
their generous cooperation: Dr. Marie L. Bauchot (MNHN) who loaned the syntypes of $M$. carinaia and the other Red Sea's materials; Dr. S.M. Shamsul Hoda (University of Karachi, Pakistan), and Drs. Adam Ben-Tuvia and Daniel Golani (The Hebrew University of Jerusalem, Israel) who gifted the specimens of L. carinata and L. klunzingeri; Dr. Alwyne Wheeler (BMNH) and Dr. P.K. Talwar (ZSI) who permitted the examination of the holotype of $M$. affinis and the syntype of $M$. klunzingeri to the second author; Mr. Masayoshi Hayashi (YCM), and Dr. Katsuzo Kuronuma and Dr. Kiyoshi Fujita (Tokyo University of Fisheries) who lent helpful specimens; Dr. Kenji Mochizuki (University Museum, University of Tokyo) who permitted use of the facilities of the University Museum.

Thanks are also due to Messrs. Hajime Masuda (Masuda Marine Production, Tokyo), Toshiyuki Suzuki (Kasumi High School, Hyogo) and Kiyotaka Hatooka (Suita Higashi High School, Osaka) for their help in collecting specimens.

This study was partly supported by grants from the Ito Foundation for the Advancement of Ichthyology to the senior author.

\section{References}

Ben-Tuvia, A. 1966. Red Sea fishes recently found in the Mediterranean. Copeia, 1966: 254-275.

- 1975. Mugilid fishes of the Red Sea with a key to the Mediterranean and Red Sea species. Bamidgeh (Bull. Fish Culture in Israel), 27: 14-20.

Blanc, M. \& J.-C. Hureau. 1972. Catalogue critique des types de Poissons du Muséum national d'Histoire naturelle. Suite. Mugiliformes et Polynémiformes. Bull. Mus. Nat. Hist. Natur., Sér. 3, Zool., 15: 673-734.

Chu, Y. et al. 1962. Fishes of the South China Sea. xxxvii +1184 pp. Sci. Publ. Agency, Peking. (In Chinese)

Chu, Y., T. Tchang \& C. Cheng. 1963. Fishes of the East China Sea. xxviii +642 pp. Sci. Publ. Agency, Peking. (In Chinese)

Guvier, G. \& A. Valenciennes. 1836. Histoire naturelle des poissons. Vol. 11. xxii +506 pp., pls 307-343. Paris-Strasbourg.

Day, F., 1865. The fishes of Malabar. xxxii +293 pp., 20 pls. Bernard Quaritch, London.

- 1876. The fishes of India, being a natural history of the fishes known to inhabit the seas and freshwaters of India, Burma, and Ceylon. Part II. Pp. 169-368, pls 41-78. William Dawson \& Sons, London.

- 1888a. Observations on the fishes of India. Part I. Proc. Zool. Soc. Lond., 1888: 258-265.

-1888b. Fishes of India. Supplement. Pp. 779-816. William Dawson, London.

- 1889. The fauna of British India, including Ceylon and Burma. Vol. II. xiv $+509 \mathrm{pp}$. Taylor and Francis, London.

Dor, M. 1984. GLOFRES: Checklist of the fishes of the Red Sea. xxii +437 pp., 1 col. fig., 2 maps. Israel Acad. Sci. Humanities, Jerusalem.

Ebeling, A.W. 1957. The dentition of Eastern Pacific mullets, with special reference to adaptation and taxonomy. Copeia, 1957: 173-185.

Grant, G.J. \& A.V. Spain. 1975. Reproduction, growth and size allometry of Mugil cephalus Linnaeus (Pisces: Mugilidae) from North Queensland inshore waters. Austr. J. Zool., 23: 181-201.

Günther, A. 1861. Catalogue of the fishes in the British Museum. Vol. III. xxv +586 pp. Trustees, British Museum, London.

Harada, I. 1943. Freshwater fishes of Hainan Island. 114 pp., 28 pls. Hainan Navy. (In Japanese)

Hubbs, G.L. \& K.F. Lagler. 1947. Fishes of the Great Lakes region. Bull. Cranbrook Inst. Sci., 26: i-xi, 1-186, pls 1-26.

Kamohara, T. 1954. Eleven additions to the fish fauna of Prov. Tosa, including one new species of the family Serranidae. Res. Rep. Kochi Univ., 3(26): 1-6.

1957. List of fishes from Amami-Oshima and adjacent regions, Kagoshima Prefecture, Japan. Rep. Usa Mar. Biol. Stat., 4: 1-65. 
Kamohara, T. \& T. Yamakawa. 1967. On some fishes from the waters of Okinawa and Yaeyama. Rep. Usa Mar. Biol. Stat., 14: 1-16.

Kuronuma, K. \& Y. Abe. 1986. Fishes of the Arabian Gulf. xii+356 pp., 30 pls. Kuwait Inst. Sci. Res., Kuwait.

Liang, S. 1986. Mugiliformes. In: Pearl River Fisheries Research Institute, Chinese Academy of Fisheries Science et al. (eds). The freshwater and estuaries fishes of Hainan Island. Pp. 202-210. Guangdong Science and Technology Press, Guangzhou, China. (In Chinese)

Matsubara, K. 1955. Fish morphology and hierarchy. Part I. xi+789 pp. Ishizaki-Shoten, Tokyo. (In Japanese)

Mohr, E. 1927. Mugiliden-Studien. Zool. Jahrb., 54: 177-202.

Mori, T. 1952. Check list of the fishes of Korea. Mem. Hyogo Univ. Agr., 1 (3): 1-228, with a map.

Oshima, M. 1919. Contributions to the study of the fresh water fishes of the Island of Formosa. Ann. Carnegie Mus., 12: 169-328, pls 48-53.

Oshima, M. 1922. A review of the fishes of the family Mugilidae found in the waters of Formosa. Ann. Carnegie Mus., 13: 240-259, pls 11-13.

Pillay, S. 1962. A revision of Indian Mugilidae. Part I \& II. J. Bombay Nat. Hist. Soc., 59: 254270; 59: 547-576, pls 1-2.

Schmidt, P.J. 1930. Fishes of the Riu-Kiu Islands. Trans. Pacific Comm. Acad. Sci. USSR, 1: $19-156$, pls $1-6$.

Senou, H. \& T. Kitamura. 1982. The fishes at tidal influenced zone of the Kamogawa River, Wakayama Prefecture, Japan I. Nankiseibutu, 24: 36-42. (In Japanese)

Senou, H. \& T. Suzuki. 1980a. The inland water fishes of the Yaeyama Islands, Okinawa Prefecture, Japan I. The Freshwater Fishes, 6: 54-65, pls 1-8. (In Japanese)

. \& 1980b. The inland water fishes of the Yaeyama Islands, Okinawa Prefecture, Japan II. Nankiseibutu, 22: 65-70, pls 1-2. (In Japanese)

Song, J.-K. 1981. Chinese mugilid fishes and morphology of their cephalic lateral-line canals. Sinozoologia, 1: 9-21, pl. 1. (In Chinese)

Suzuki, K. 1964. Results of Amami-Expedition. Rep. Fac. Fish., Pref. Univ. Mie, 5: 153-188.

Suzuki, T., Y. Dotsu \& H. Senou. 1982. Inland water fish fauna of the Yaeyama Group, the Ryukyu Islands. Biol. Mag. Okinawa, 20: 17-23. (In Japanese)

Thomson, J.M. 1964. A bibliography of systematic references to the grey mullets (Mugilidae). Div. Fish. Oceanogr., CSIRO, Tech. Pap., 16: 1-127.

. 1984. Mugilidae. In: W. Fischer \& G. Bianchi (eds.). FAO species identification sheets for fishery purposes, western Indian Ocean (fishing area 51), FAO, Rome. (No pagination)

Trewavas, E. 1973. Mugilidae. In: J.C. Hureau \& Th. Monod (eds.). GLOFNAM: Check-list of the fishes of the north-eastern Atlantic and of the Mediterranean. Vol. 1. Pp. 567-574. Unesco, Paris.

Trewavas, E. \& S.E. Ingham. 1972. A key to the species of Mugilidae (Pisces) in the northeastern Atlantic and Mediterranean, with explanatory notes. J. Zool., Lond., 167: 15-29.

Whitehead, P.J.P. \& P.K. Talwar. 1976. Francis Day (1829-1889) and his collections of Indian fishes. Bull. British Mus. (Nat. Hist.), Hist. Ser., 5: 1-189, pls 1-4.

Yoshino, T. \& H. Senou. 1984. Mugilidae. In: H. Masuda, K. Amaoka, C. Araga, T. Uyeno \& T. Yoshino (eds.). The fishes of the Japanese Archipelago. Pp. 119-121, pls 104-105, 347. Tokai Univ. Press, Tokyo. (English ed.) 